\title{
CONCENTRATION AND COMPETITION \\ OF CONTAINER PORTS IN TURKEY: A STATISTICAL ANALYSIS*
}

\author{
Seçil VARAN ${ }^{1}$ \\ A. Güldem CERIT ${ }^{2}$
}

\begin{abstract}
Literature implies that in developing countries, the level and nature of public investments should be adjusted to stimulate private investments for economic growth. This study aims to assess the outcome of Turkey's recent privatization process by analyzing the industry concentration and competition in the specific context of container ports. For this purpose, the concentration dynamics of Turkish container ports are examined by applying statistical measures of market concentration and competition throughout the port privatization period. The statistical findings of this study suggest that the recent port privatizations have been successful in stimulating private investments and competition. However, for the post-privatization performance, macro-economic and institutional factors are influential. Therefore, the continuous improvements in the port policy and regulatory framework are required for using the competitive advantage of the newcomers to the sector as a future advantage for Turkey's global competitiveness.
\end{abstract}

Keywords: Public-private investment, container ports, concentration, competition, turkey.

\footnotetext{
${ }^{*}$ A previous version of this study was presented at EURAM 2013, 13th Annual Conference of the European Academy of Management, 26-29 June 2013, Istanbul, Turkey.

${ }^{1}$ Dokuz Eylül Üniversitesi, Denizcilik Fakültesi, Tınaztepe Kampüsü, İzmir, secil.varan@deu.edu.tr

${ }^{2}$ Dokuz Eylül Üniversitesi Denizcilik Fakültesi, Tınaztepe Kampüsü, İzmir, gcerit@deu.edu.tr
} 


\title{
TÜRKIYYE'DEKI KONTEYNER LIMANLARINDA YOĞUNLASMA VE REKABET: ISTATISTIKSEL BIR ANALIZ
}

$\ddot{O Z Z E T}$

\begin{abstract}
Araştırmalara göre, gelişmekte olan ülkelerde ekonomik büyümenin sağlanması için, kamu yatırımlarının mahiyeti, özel sektör yatırımlarını teşvik edecek şekilde ayarlanmalıdır. Bu çalışmanın amacı, Türkiye'deki güncel özelleştirme sürecini, konteyner limanlart açısından değerlendirmektir. Bu amaçla, Türkiye'deki konteyner limanlarındaki yoğunlaşma ĕgilimleri ve rekabet şartları, özelleştirme dönemi boyunca, istatistiksel ölçütler ile incelenmiştir. Çalışmanın bulgularına göre, Türkiye'deki limanların özelleştirilmesi süreci, özel sektör yatırımlarının teşviki açısından başarılıdır. Ancak, özelleştirme sonrası liman performansında makroekonomik ve kurumsal faktörler önemlidir. Bu nedenle, sektöre yeni giren yatırımcıların rekabet avantajlarının Türkiye için küresel bir rekabet gücüne dönüşebilmesinde liman politikalart ve sektörel düzenlemelerin sürekli gelişimi gerekmektedir.
\end{abstract}

Anahtar Kelimeler: Kamu-özel sektör yatırımlarl, konteyner limanlarl, yoğunlaşma, rekabet, türkiye.

\section{INTRODUCTION}

In accordance with the economic policies, the privatization experience in Turkey began in the mid-1980s and accelerated in 1990s. In this context, major port privatizations took place after 1997. The continuing privatization process of ports in Turkey aims to improve the level of port efficiency and performance, since ports are vital instruments of national economic policy (Nagorski, 1972), and efficient ports influence a country's competitiveness due to their role in constituting a critical link in the overall logistics or supply chain (Cullinane and Song, 2002:59).

D'Souza et al. (2005: 747) and Boubakri et al. (2005: 767) report that the determinants of post-privatization performance differ in developed and developing countries. In developed countries, firmlevel factors are the most significant, whereas in developing countries macro-economic and institutional factors are influential, emphasizing institution-building in emerging countries. It is crucial to note here that, by means of post-privatization performance, the significant factor is not the post-performance of the ports that are privatized, yet the port industry of a country. This study argues that the recent port privatizations in Turkey have been successful in terms of stimulating private investments and competition. 
Djankov and Murrell (2002), Newbery and Pollitt (1997), and D'Souza et al. (2005) point out that competition is a major determinant of post-privatization performance. According to D'Souza et al. (2005: 750) privatization may trigger competition, and aiming more market share may provide the pressure required to stimulate greater efficiency and profitability. Khan and Kumar (1997: 69) call attention to the "crowding-out" effects of the public investments, and they argue that the level and nature of public investments should be adjusted to stimulate private investments, especially in developing countries, for economic growth. Public investments may be complementary or substitutes of private sector, as infrastructure investments by public trigger private investments in an economy. However, public enterprises may also be substitutes as competitors of private investors in an industry. In this case, since the incentive of public sector is not solely profit maximization, the private sector may be "crowded out" due to their budget constraints. Therefore, privatization is a way of stimulating private sector investments in an industry, especially if the industry is concentrated on public enterprises in terms of market share (Khan and Kumar, 1997: 84).

This study aims to assess the outcome of Turkey's recent privatization process by analyzing the industry concentration and competition in the specific context of container ports. Turkey is an interesting setting for this investigation because regarding container ports, when cargo traffic was less containerizable, ports comprised a lot of labor intensive activities which added direct and indirect values to the national economy that led to higher public investments (Haralambides, 2002: 326). Port efficiency was less of an argument, and due to national borders, trade barriers, and infrastructure problems, port competition was less of an issue. Trade liberalization and developments in technologies changed the big picture towards a more competitive environment that necessitates port efficiency. However, major public ports in Turkey appeared not to be operated efficiently (Oral et. al., 2007: 183). The port industry in Turkey that was owned by state enterprises left behind the global industrial developments until the privatization process took place (Caglar et. al, 2010: 925). Additionally, the privatization process faced the risk of 2001 financial crises in Turkey that tightened the funding of private sector, and also 2008-2009 global financial crises that hit the shipping industry throughout the world.

According to Niekerk (2005: 155), port reforms should be measured in terms of economic efficiency gains and the motto should 
be "private gain, public gain and not private gain, public loss". In this study, the concentration dynamics of Turkish container ports are examined by using statistical measures of market concentration and competition throughout the port privatization period. The results suggest that the recent port privatizations have been successful in stimulating private investments and competition.

\section{LITERATURE REVIEW}

Since the container port industry concentration and competition are analyzed, a literature survey on port concentration and competition is realized. Table 1 provides a detailed review of the relevant literature.

The argument that "Containerization would lead to further port concentration" is not confirmed by the literature. As Notteboom (1997: 114) points out the concentration eventually reaches a limit or might even change into de-concentration. Micco and Perez (2001: 3) point out that seaport monopoly power is either reduced by competition or adequately regulated. Tongzon and Heng (2005: 405) imply that private sector participation in the port industry improves port operation efficiency, which will in turn boost port competitiveness. Overall, the literature survey suggests that the current developments of world trade invited a more competitive environment for port industry by means of both mergers, and regional or global expansion which mutually led to a greater role for private investments. Another outcome of the literature survey is that the private sector participation in the port industry improves efficiency and competition. 
Table 1. Literature Review on Concentration and Competition of Ports

\begin{tabular}{|c|c|c|c|c|}
\hline $\begin{array}{c}\text { Author(s) \& } \\
\text { Journal }\end{array}$ & Title & Methodology & $\begin{array}{c}\text { Research } \\
\text { Area }\end{array}$ & $\begin{array}{c}\text { Main } \\
\text { Contributions }\end{array}$ \\
\hline $\begin{array}{c}\text { Heaver (1995) } \\
\text { Maritime Policy } \\
\& \text { Management }\end{array}$ & $\begin{array}{l}\text { The implications } \\
\text { of increased } \\
\text { competition } \\
\text { among ports for } \\
\text { port policy and } \\
\text { management }\end{array}$ & Conceptual & 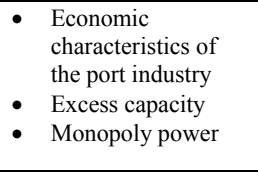 & $\begin{array}{l}\text { More competent } \\
\text { environment leads to a } \\
\text { greater role for private } \\
\text { enterprise }\end{array}$ \\
\hline $\begin{array}{l}\text { Estache et. al. } \\
\text { (2002) } \\
\text { World } \\
\text { Development }\end{array}$ & $\begin{array}{l}\text { Efficiency Gains } \\
\text { from Port } \\
\text { Reform and the } \\
\text { Potential for } \\
\text { Yardstick } \\
\text { Competition: } \\
\text { Lessons from } \\
\text { Mexico }\end{array}$ & $\begin{array}{l}\text { Stochastic } \\
\text { Production } \\
\text { Frontier }\end{array}$ & $\begin{array}{l}\text { Measures of relative } \\
\text { efficiency } \\
\text { performance and } \\
\text { competition } \\
\text { between port } \\
\text { infrastructure } \\
\text { operators }\end{array}$ & $\begin{array}{l}\text { - Competition between } \\
\text { ports will improve the } \\
\text { competitiveness of the } \\
\text { ports. } \\
\text { - Effective competition } \\
\text { will guarantee the } \\
\text { sustainability of the gains }\end{array}$ \\
\hline $\begin{array}{c}\text { Heaver et al. } \\
(2001) \\
\text { Maritime Policy } \\
\text { \& Management }\end{array}$ & $\begin{array}{c}\text { Co-operation } \\
\text { and competition } \\
\text { in international } \\
\text { container } \\
\text { transport: } \\
\text { strategies for } \\
\text { ports }\end{array}$ & Conceptual & $\begin{array}{l}\text { Potential conflicts } \\
\text { of interest for a port } \\
\text { authority in matters } \\
\text { related to the level } \\
\text { of competition } \\
\text { amongst terminals } \\
\text { and the amount of } \\
\text { competition } \\
\text { amongst ports. }\end{array}$ & $\begin{array}{l}\text { Port authorities are } \\
\text { adopting new strategies, } \\
\text { and new companies are } \\
\text { emerging in container } \\
\text { management. } \\
\text { Mergers, regional and } \\
\text { global expansion are } \\
\text { changing the structure of } \\
\text { the old stevedoring } \\
\text { business. }\end{array}$ \\
\hline $\begin{array}{c}\text { Fleming and } \\
\text { Baird (1999) } \\
\text { Maritime Policy } \\
\text { \& Management }\end{array}$ & $\begin{array}{l}\text { Comment Some } \\
\text { reflections on } \\
\text { port competition } \\
\text { in the United } \\
\text { States and } \\
\text { western Europe }\end{array}$ & Conceptual & $\begin{array}{l}\text { In seaports that } \\
\text { contain complex } \\
\text { and changeable } \\
\text { mixtures of public } \\
\text { and private } \\
\text { enterprise, who } \\
\text { competes and why? }\end{array}$ & $\begin{array}{l}\text { - The commercial system } \\
\text { works better without } \\
\text { much government } \\
\text { interference. } \\
\text { - To private enterprises, } \\
\text { competition usually has } \\
\text { formal economic } \\
\text { meaning and offers } \\
\text { certain well-known } \\
\text { benefits as the advocates } \\
\text { of port privatization } \\
\text { publicized. }\end{array}$ \\
\hline $\begin{array}{l}\text { Haralambidas } \\
(2002) \\
\text { International } \\
\text { Journal of } \\
\text { Maritime } \\
\text { Economics }\end{array}$ & $\begin{array}{l}\text { Competition, } \\
\text { Excess } \\
\text { Capacity, and } \\
\text { the Pricing of } \\
\text { Port } \\
\text { Infrastructure }\end{array}$ & Conceptual & $\begin{array}{l}\text { Port pricing and } \\
\text { competition with } \\
\text { special emphasis on } \\
\text { container ports }\end{array}$ & $\begin{array}{l}\text { To succeed in fair } \\
\text { competition, stronger } \\
\text { policy intervention to } \\
\text { ensure greater } \\
\text { transparency of port } \\
\text { accounting systems, } \\
\text { more harmonized port } \\
\text { statistics, a meaningful } \\
\text { set of state aid guidelines } \\
\text { are necessary. }\end{array}$ \\
\hline $\begin{array}{l}\text { Notteboom } \\
\text { (1997) } \\
\text { Journal of } \\
\text { Transport } \\
\text { Geography }\end{array}$ & $\begin{array}{l}\text { Concentration } \\
\text { and load centre } \\
\text { development in } \\
\text { the European } \\
\text { container port } \\
\text { system }\end{array}$ & $\begin{array}{l}\text { HHI, Gini } \\
\text { Coefficient, } \\
\text { Share-Shift } \\
\text { Analysis }\end{array}$ & $\begin{array}{l}\text { To examine } \\
\text { dynamics - in } \\
\text { particular, } \\
\text { concentration and } \\
\text { de-concentration } \\
\text { tendencies and load } \\
\text { centre development } \\
\text { - in the European } \\
\text { continental } \\
\text { container port } \\
\text { system for the } \\
\text { period 1980-1994. }\end{array}$ & $\begin{array}{l}\text { - "Containerization would } \\
\text { lead to further port } \\
\text { concentration" is not } \\
\text { confirmed. } \\
\text { - The concentration } \\
\text { eventually reaches a limit } \\
\text { or might even develop } \\
\text { into de-concentration. }\end{array}$ \\
\hline
\end{tabular}


Table 1. continued

\begin{tabular}{|c|c|c|c|c|}
\hline $\begin{array}{c}\text { Author(s) \& } \\
\text { Journal }\end{array}$ & Title & Methodology & $\begin{array}{c}\text { Research } \\
\text { Area }\end{array}$ & $\begin{array}{c}\text { Main } \\
\text { Contributions } \\
\end{array}$ \\
\hline $\begin{array}{l}\text { Niekerk (2005) } \\
\text { Maritime } \\
\text { Economics \& } \\
\text { Logistics }\end{array}$ & $\begin{array}{l}\text { Post reform and } \\
\text { Concessioning } \\
\text { in Developing } \\
\text { Countries }\end{array}$ & Conceptual & $\begin{array}{l}\text { - Implications of } \\
\text { concessioning } \\
\text { under such } \\
\text { circumstances of } \\
\text { regulated } \\
\text { competition }\end{array}$ & $\begin{array}{l}\text { - Port reform should not be } \\
\text { pursued merely for the } \\
\text { sake of political ideology } \\
\text { or the gain of private } \\
\text { operators. } \\
\text { - The motto should be } \\
\text { private gain, public gain } \\
\text { and not private gain, } \\
\text { public loss }\end{array}$ \\
\hline $\begin{array}{c}\text { Tongzon and } \\
\text { Heng (2005) } \\
\text { Transportation } \\
\text { Research Part A }\end{array}$ & $\begin{array}{l}\text { Port } \\
\text { privatization, } \\
\text { efficiency and } \\
\text { competitiveness: } \\
\text { Some empirical } \\
\text { evidence from } \\
\text { container ports } \\
\text { (terminals) } \\
\end{array}$ & $\begin{array}{l}\text { Stochastic } \\
\text { frontier } \\
\text { production } \\
\text { function, } \\
\text { Survey }\end{array}$ & $\begin{array}{l}\text { Determinants of } \\
\text { port } \\
\text { competitiveness }\end{array}$ & $\begin{array}{l}\text { Private sector } \\
\text { participation in the port } \\
\text { industry improves port } \\
\text { operation efficiency, } \\
\text { which will in turn boost } \\
\text { port competitiveness. }\end{array}$ \\
\hline $\begin{array}{l}\text { Micco and Perez } \\
\text { (2001) } \\
\text { Towards } \\
\text { Competitiveness: } \\
\text { The Institutional } \\
\text { Path, Seminar }\end{array}$ & $\begin{array}{c}\text { Maritime } \\
\text { Transport Costs } \\
\text { and Port } \\
\text { Efficiency }\end{array}$ & $\begin{array}{c}\text { OLS } \\
\text { regressions }\end{array}$ & $\begin{array}{ll}\text { - } & \text { Determinants of } \\
\text { seaport efficiency }\end{array}$ & $\begin{array}{l}\text { Private involvement } \\
\text { increases port efficiency } \\
\text { with labor reforms and } \\
\text { seaport monopoly is } \\
\text { either reduced by } \\
\text { competition or } \\
\text { adequately regulated. }\end{array}$ \\
\hline $\begin{array}{c}\text { Slack and } \\
\text { Fremont (2005) } \\
\text { Transport } \\
\text { Reviews }\end{array}$ & $\begin{array}{l}\text { Transformation } \\
\text { of Port Terminal } \\
\text { Operations: } \\
\text { From the Local } \\
\text { to the Global }\end{array}$ & Conceptual & $\begin{array}{l}\text { Bases for the } \\
\text { internationalization } \\
\text { of the port terminal } \\
\text { industry }\end{array}$ & $\begin{array}{l}\text { For internationalization, } \\
\text { cost differentials are not } \\
\text { the only determinant, and } \\
\text { that governance, } \\
\text { institutional relationships } \\
\text { and spatial competition, } \\
\text { factors that are regionally } \\
\text { differentiated, are } \\
\text { additional considerations. }\end{array}$ \\
\hline $\begin{array}{l}\text { Liu et al. (2011) } \\
\text { Working Paper }\end{array}$ & $\begin{array}{l}\text { An Analysis of } \\
\text { the Competition } \\
\text { of Ports in the } \\
\text { Shanghai } \\
\text { International } \\
\text { Shipping Hub }\end{array}$ & $\begin{array}{l}\text { HHI, Share- } \\
\text { Shift } \\
\text { Analysis }\end{array}$ & $\begin{array}{l}\text { Concentration and } \\
\text { competition in the } \\
\text { Shanghai } \\
\text { International } \\
\text { Shipping Hub with } \\
\text { its two main ports. }\end{array}$ & $\begin{array}{l}\text { The degree of } \\
\text { concentration of port } \\
\text { system and the } \\
\text { competitiveness of port } \\
\text { depend on both natural } \\
\text { conditions and the } \\
\text { developed hinterland }\end{array}$ \\
\hline $\begin{array}{l}\text { Notteboom } \\
(2010) \\
\text { Journal of } \\
\text { Transport } \\
\text { Geography }\end{array}$ & $\begin{array}{l}\text { Concentration } \\
\text { and the } \\
\text { Formation of } \\
\text { Multi-Port } \\
\text { Gateway } \\
\text { Regions in the } \\
\text { European } \\
\text { Container Port } \\
\text { System: an } \\
\text { Update }\end{array}$ & HHI & $\begin{array}{l}\text { Trends and issues } \\
\text { underlying recent } \\
\text { developments in the } \\
\text { European container } \\
\text { port system. }\end{array}$ & $\begin{array}{l}\text { Routing flexibility is a } \\
\text { keystone for the logistics } \\
\text { attractiveness of a region }\end{array}$ \\
\hline $\begin{array}{c}\text { Fageda } \\
(2011) \\
\text { 40th Congress } \\
\text { European Regional } \\
\text { Science Assoc. }\end{array}$ & $\begin{array}{l}\text { Load Centers in the } \\
\text { Mediterranean Port } \\
\text { Range. Ports Hub } \\
\text { and Ports Gateway }\end{array}$ & $\begin{array}{c}\text { HHI, Gini } \\
\text { Coefficient, } \\
\text { Share-Shift } \\
\text { Analysis }\end{array}$ & $\begin{array}{l}\text { Competition among } \\
\text { main Mediterranean } \\
\text { ports for becoming the } \\
\text { dominant port of the } \\
\text { system }\end{array}$ & $\begin{array}{l}\text { - Gini coefficient can produce } \\
\text { wrong results when we } \\
\text { examine a port system with } \\
\text { a small number of ports. } \\
\text { - Strategies, investments, } \\
\text { price policies are required. }\end{array}$ \\
\hline $\begin{array}{c}\text { Notteboom (2012) } \\
\text { Workshop Milan, } \\
18 \text { April }\end{array}$ & $\begin{array}{l}\text { Dynamics in port } \\
\text { competition in } \\
\text { Europe: }\end{array}$ & $\begin{array}{l}\text { Share-Shift } \\
\text { Analysis }\end{array}$ & $\begin{array}{l}\text { Position of the } \\
\text { dynamics in port } \\
\text { competition in Europe. }\end{array}$ & $\begin{array}{l}\text { Container handling market is } \\
\text { far more concentrated than } \\
\text { other cargo handling }\end{array}$ \\
\hline
\end{tabular}




\begin{tabular}{|l|l|l|l|l|}
\hline & $\begin{array}{c}\text { implications for } \\
\text { North Italian ports }\end{array}$ & & $\begin{array}{l}\text { segments in the European } \\
\text { port system }\end{array}$ \\
\hline
\end{tabular}

Source: Author(s)

Regarding the methodologies for the measurement of concentration and competition, Herfindahl-Hirschman Index (HHI), Gini Coefficient and Share-Shift analysis are the most preferred methods. Fageda (2011: 8) suggests that Gini coefficient can produce wrong results when a port system with a small number of ports is analyzed.

\section{STATISTICAL ANALYSIS}

\subsection{Methodology}

For the analysis of the concentration and competition dynamics during the privatization period, concentration is measured by HHI and concentration ratios that are commonly accepted as market concentration measures (Notteboom, 2010, Liu et al., 2011). For a better assessment of port competition, a shift-share analysis is performed following Notteboom (1997), Liu et al. (2011), and Fageda (2011).

HHI measures the degree of concentration in an industry and it is calculated by squaring the market share of each company competing in a market, and then summing the resulting numbers. HHI can range from close to zero to one. A higher HHI indicates less market competition (Zhang and Zhang, 2001).

Concentration ratios $\left(\mathrm{CR}_{3}\right.$ and $\left.\mathrm{CR}_{5}\right)$ express the degree of competition in a national industry and high ratios may act as barriers to entry of new investors (Chen and Liao, 2011, Williams, 2003).

Notteboom (1997) points out that by the shift-share analysis, the growth or decline of ports may be examined; 'share' effect shows the expected growth of container traffic in a port and the total shift indicates the total throughput a port has lost to or won from competing ports in the same range, with the expected container traffic (share effect) as a reference.

\subsection{Sample}

Since the major port privatizations took place after 1996 in Turkey, in accordance with the aim of the study, the period between 
1996 and 2011 is covered. Total throughputs of all container ports that are operating during the sample period are used for the analysis. Data are obtained from the web pages of the Ministry of Transport, Maritime Affairs and Communications (http://www.ubak.gov.tr), Port Operators Association of Turkey (http://www.turklim.org/tr/liman/liste), and TÜRKLIM (2012).

Table 2 shows the number of container ports used in the analysis and total throughput in Turkey by years. It can be seen that the number of operating container ports increased from 10 to 21 and total throughput rose up from 981,653 TEU to $6,613,035$ TEU in 15 years.

\subsection{Data Analysis}

The statistical analysis is applied firstly, by examining Herfindahl-Hirschman Index (HHI) of Turkish container ports as a proxy for the degree of domestic market competition (Zhang and Zhang, 2001), since competition is inversely related to concentration (Jimenaz et al., 2006).

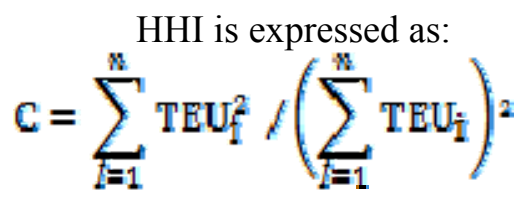

Where;

ports system;

$$
C=\text { the degree of concentration of the container }
$$

$$
\begin{array}{ll}
T E U i & =\text { the container throughputs of port } i \\
n & =\text { the total number of the ports. }
\end{array}
$$

Commonly, concentration exists in an industry when HHI is larger than 0.1; and it indicates that the system is highly concentrated when HHI is larger than 0.18 (Liu et al., 2011).

Secondly, concentration ratios are estimated by squaring the market shares of the three $\left(\mathrm{CR}_{3}\right)$ and five $\left(\mathrm{CR}_{5}\right)$ (Bikker and Haaf, 2002) biggest container ports in Turkey in terms of TEU that is inversely related with competition as well.

$\mathrm{CR}_{3}$ and $\mathrm{CR}_{5}$ are expressed as:

$$
\mathrm{CR}_{3}=\mathrm{s}_{1}^{2}+\mathrm{s}_{2}^{2}+\mathrm{s}_{3}^{2}
$$




$$
\mathrm{CR}_{5}=s_{1}^{2}+s_{2}^{2}+s_{2}^{2}+s_{4}^{2}+s_{\mathrm{E}}^{2}
$$

Where;

comprising $n$ ports.

$$
s \quad=\text { the market share of the } i^{\text {th }} \text { port in the system }
$$

Then, the shift-share analysis is performed for examining a port's competitiveness. Shift-Share effect is expressed as follows by Notteboom (1997), Liu et al. (1999), and Fageda (2011):

$$
\begin{aligned}
& \text { ABSGR }_{\mathrm{i}}=\text { TEUit }_{1}-\text { TEUit }_{0}=\text { SHARE }_{\mathrm{i}}+\text { SHIFT }_{\mathrm{i}} \\
& \mathrm{SHARE}_{\mathrm{i}}=\left(\left(\mathrm{TEUit}_{1} / \mathrm{TEUit}_{0}\right)-1\right)^{*} \mathrm{TEUit}_{0}
\end{aligned}
$$

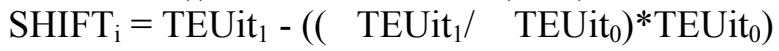

$$
\begin{aligned}
& \text { SHIFT }=\text { total shift of port } i \text { in the period } t_{0}-t_{1}
\end{aligned}
$$

\section{RESULTS}

\subsection{Results for the Concentration Measures}

Table 3 shows the statistical measures of concentration for Turkish container ports for the period 1996-2011. According to Table 3 , prior to the privatization process, all three measures of concentration were equal to 0.27 , suggesting a very high concentration. High value of $\mathrm{CR}_{3}$ in particular, reflects that the industry was concentrated in the three biggest container ports in terms of TEU which may result from the introduction stage of the industry. High value of $\mathrm{CR}_{3}$ may also act as a barrier to the entry of new investors according to the literature (Chen and Liao, 2011, Williams, 2003).

However, after 1996, a declining concentration trend might be observed, specifically for $\mathrm{CR}_{3}$, suggesting an increased competition amongst container ports. As of 2011, $\mathrm{CR}_{5}$ and $\mathrm{HHI}$ is 0.11 and 0.12 respectively indicating a modest concentration. Additionally, $\mathrm{CR}_{3}$ is slightly less than 0.1 suggesting a tendency to de-concentration. 
Figure 1 reflects the changes in the main actors of the industry throughout the sample period. It can be observed that before 2000, the three biggest container ports in terms of throughputs were owned by the state, however after 2005, the dominancy passed into private ports. As of 2011, the three main actors of the industry are private and the second largest port is Mersin International Port (MIP) that is privatized officially on May 11, 2007.

Figure 2 shows the total throughput (TEU) by regions. After 2000, Marmara region draw away probably due to the increased investments and Mediterranean region overcomes Aegean region as of 2007, following the privatization of MIP.

\subsection{Results for the Shift-Share Analysis}

Results of the shift-share analysis are reported in Figure 3 and Figure 4. Since after 2005 the dominancy in throughput in terms of TEU passed into private ports, the period 1996-2005 and 2006-2011 are examined in different figures. According to the results, in Turkey, particularly in the post 2005 period, the winners that have the competitive advantage are the newest private container ports as Nemport, Evyap, Yilport, Mardas, and TCEEge. However, the state ports as Haydarpasa and Izmir show negative values in the shift analysis. (The privatization process of Izmir/Alsancak port is ongoing.)

Overall, the results suggest that after 1997, a declining concentration trend has been observed amongst Turkish container ports towards a modest concentration; prior 2000, the three biggest container ports in terms of throughputs were owned by the state, however after 2005, the dominancy passed into private ports, and the new private ports have the largest competitive advantage.

The results of the study are consistent with D'Souza et al. (2005)'s determination that privatization may trigger competition. The results show that prior to 2000, the three biggest container ports in terms of throughputs were owned by the public, however post 2005, the dominancy passed into the private ports which implies lowered crowding out effect for the private investments, consistent with Khan and Kumar (1997).

\section{CONCLUSION AND FUTURE PROSPECTS}


Analyses of the relative effects of public and private investments have implications both for policy and theoretical views (Khan and Kumar, 1997).

Literature points out that competition is a major determinant of post-privatization performance. The continuing privatization process in Turkey has harmonized with the increase in the containerization in the country that has been a result of both privatization and investments of private ports.

The statistical findings of this study suggest that the process may have stimulated private sector investments and competition. Results also suggest a declining concentration trend amongst Turkish container ports towards a modest concentration, and that the new comers have the largest competitive advantage.

However, for the post-privatization performance in developing countries, literature suggests that macro-economic and institutional factors are influential, emphasizing institution-building. Therefore, the continuous improvements in the port policy and regulatory framework are required for using the competitive advantage of the newcomers to the sector as a future advantage for Turkey's global competitiveness.

Additionally as a future prospect, in line with Haralambidas (2002: 340), to succeed in fair competition among ports, stronger policy intervention in order to ensure greater transparency of port accounting systems and better and more harmonized port statistics are necessary. 
Table 2. Sample

\begin{tabular}{ccc}
\hline Year & $\begin{array}{c}\text { \# of Container Ports used } \\
\text { in the analysis }\end{array}$ & Total throughput in Turkey \\
\hline & & \\
1996 & 10 & 981,653 \\
1997 & 10 & $1,255,700$ \\
1998 & 10 & $1,365,822$ \\
2099 & 13 & $1,336,198$ \\
2001 & 14 & $1,603,557$ \\
2002 & 15 & $1,782,367$ \\
2003 & 15 & $2,151,749$ \\
2004 & 14 & $2,498,883$ \\
2005 & 17 & $3,089,156$ \\
2006 & 15 & $3,304,656$ \\
2007 & 15 & $3,822,727$ \\
2008 & 16 & $4,699,529$ \\
2009 & 16 & $5,228,154$ \\
2010 & 19 & $4,520,786$ \\
2011 & 19 & $5,866,585$ \\
& 21 & $6,613,035$
\end{tabular}

Source: http://www.ubak.gov.tr, http://www.turklim.org/tr/liman/liste

Table 3. Results of the Statistical Analysis (1996-2011)

\begin{tabular}{llll}
\hline YEAR & $\mathrm{CR}_{3}$ & $\mathrm{CR}_{5}$ & $\mathrm{HHI}$ \\
\hline fn1996 & 0.27 & 0.27 & 0.27 \\
1997 & 0.21 & 0.23 & 0.23 \\
1998 & 0.18 & 0.20 & 0.20 \\
1999 & 0.18 & 0.20 & 0.21 \\
2000 & 0.15 & 0.18 & 0.19 \\
2001 & 0.12 & 0.15 & 0.16 \\
2002 & 0.11 & 0.13 & 0.15 \\
2003 & 0.14 & 0.16 & 0.17 \\
2004 & 0.12 & 0.16 & 0.16 \\
2005 & 0.12 & 0.15 & 0.16 \\
2006 & 0.11 & 0.14 & 0.15 \\
2007 & 0.11 & 0.14 & 0.15 \\
2008 & 0.11 & 0.13 & 0.14 \\
& & 102 &
\end{tabular}




$\begin{array}{llll}2009 & 0.13 & 0.15 & 0.15 \\ 2010 & 0.12 & 0.13 & 0.14 \\ 2011 & 0.09 & 0.11 & 0.12\end{array}$

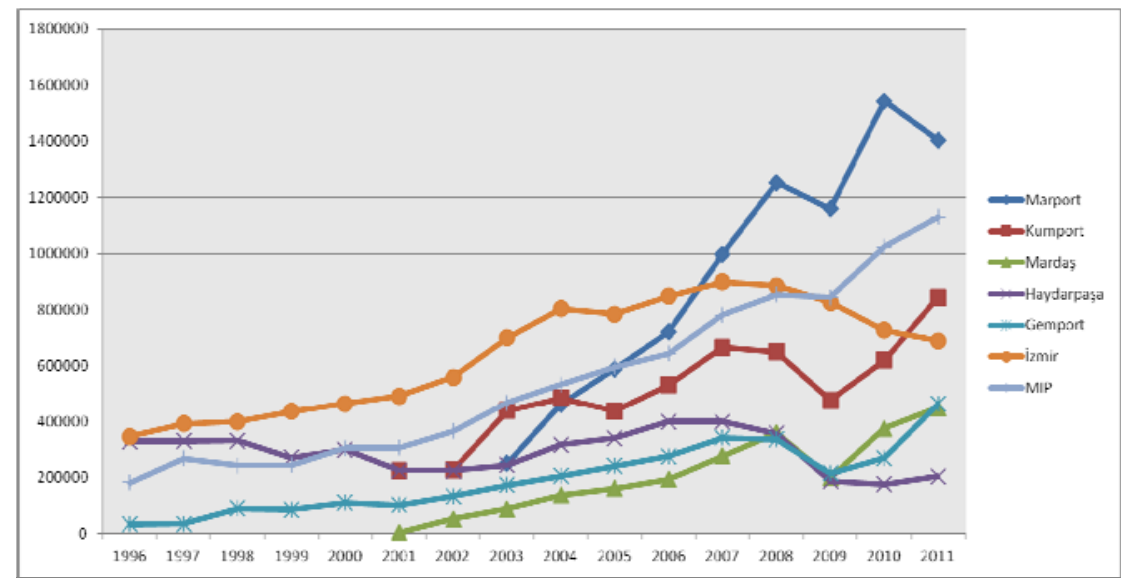

Figure 1. Total throughput by Turkish Container Ports (1996-2011)

Source: http://www.ubak.gov.tr, http://www.turklim.org/tr/liman/liste 


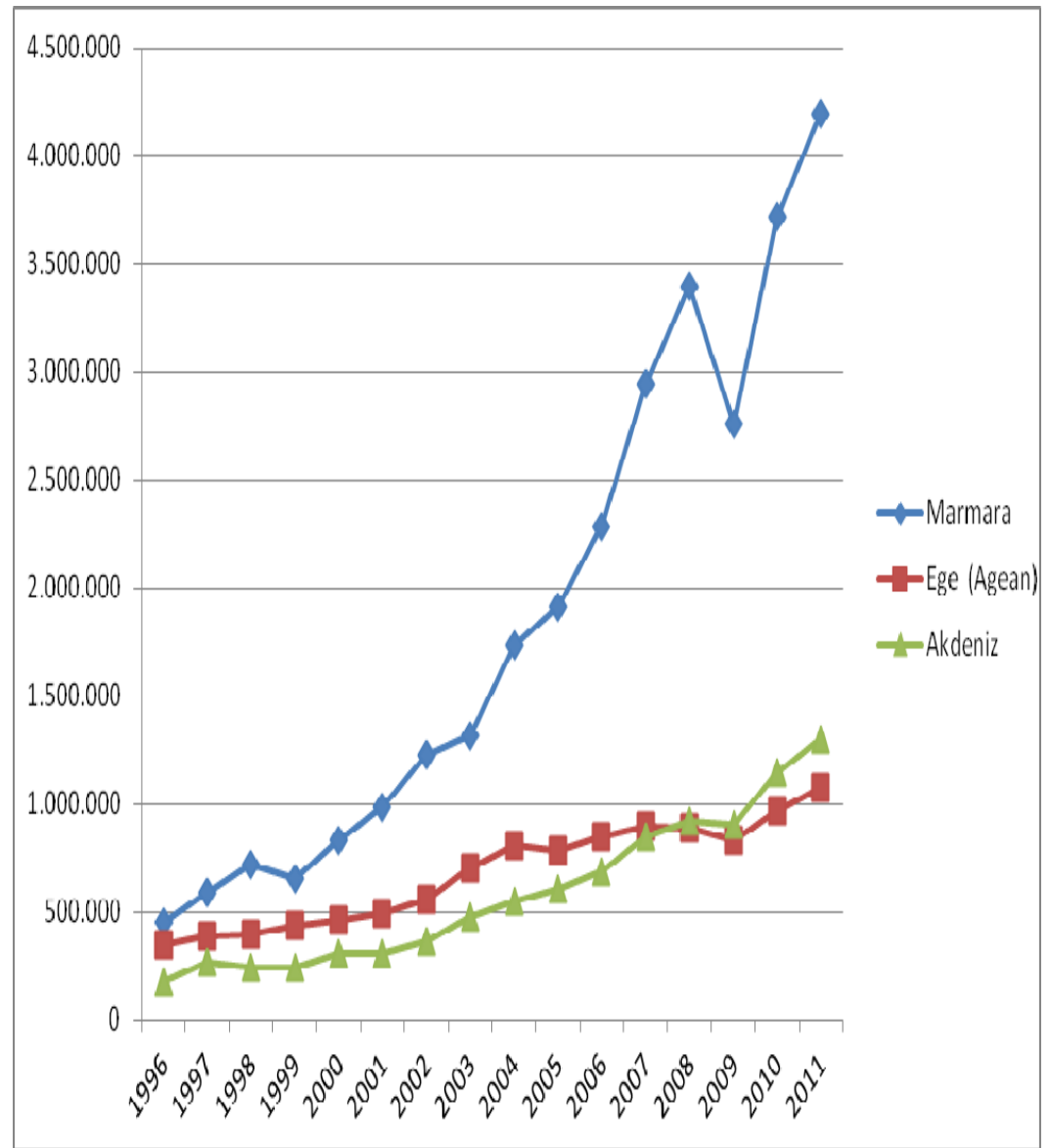

Figure 2. Total throughput of Turkish container ports by Region Source: http://www.ubak.gov.tr, http://www.turklim.org/tr/liman/liste 


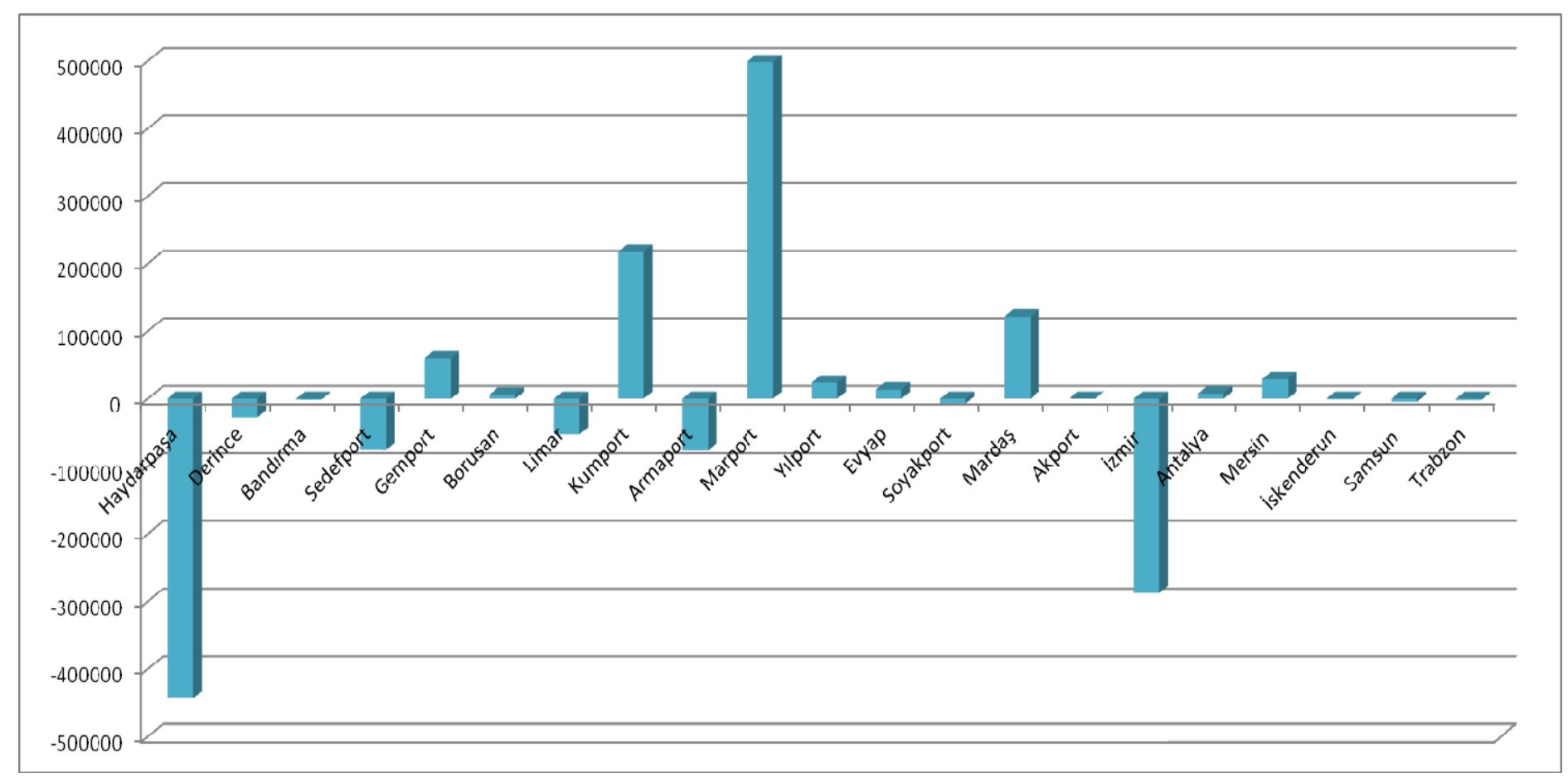

Figure 3. Results of the Shift Analysis for Turkish container ports (1996-2005) 


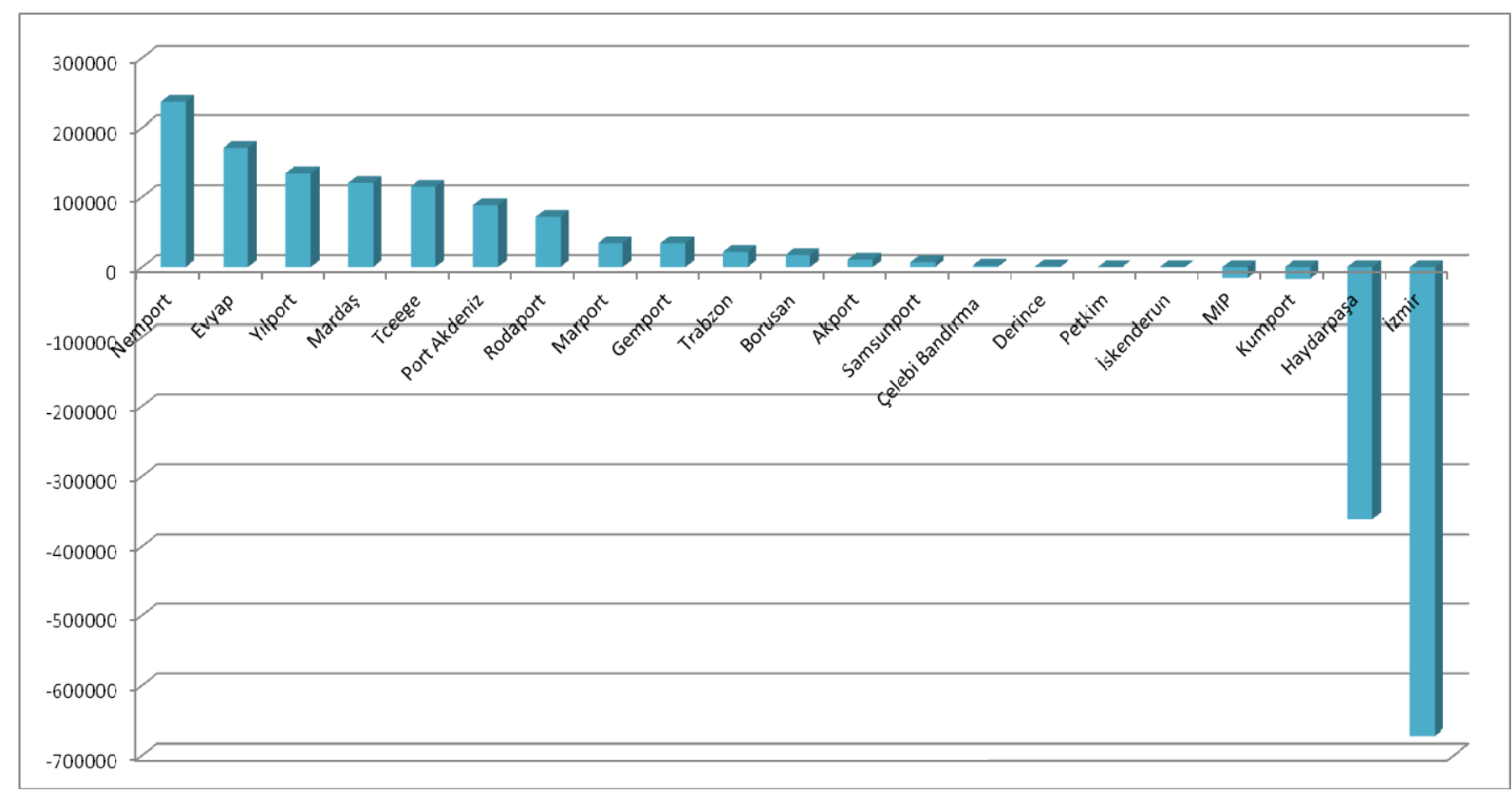

Figure 4. Results of the Shift Analysis for Turkish container ports (2006-2010) 


\section{REFERENCES}

BIKKER, J.A., HAAF, K. (2002) Competition, Concentration and Their Relationship: An Empirical Analysis of the Banking Industry, Journal of Banking and Finance, Vol. 26, pp. 2191-2214.

BOUBAKRI, N., COSSET, J., GUEDMANI, O. (2005) Liberalization, Corporate Governance, and the Performance of Newly Privatized Firms, Journal of Corporate Finance, Vol. 11, pp.767-790.

CHEN, S., LIAO, C. (2011) Are Foreign Banks more Profitable than Domestic Banks? Home- and Host-country Effects of Banking Market Structure, Governance, and Supervision, Journal of Banking and Finance, Vol. 35, pp. 819-839.

CUllinane, K., SONG, D.W. (2002) Port Privatization and Practice, Transport Reviews, Vol. 22, No.1, pp. 55-75.

ÇAĞLAR, V., ESMER, S., ORAL, E. Z. (2010) Özelleştirme ve Özelleştirme Aşamasinda Olan Limanların Sektörel İncelenmesi, 8. Türkiye'nin Kıyı ve Deniz Alanları Ulusal Kongresi Bildiriler Kitabı, pp. 925-935.

DJANKOV, S., MURRELL, P. (2002) Enterprise Restructuring in Transition: a Quantitative Survey, Journal of Economic Literature, Vol. 40, pp.739-792.

D'SOUZA, J., MEGGINSON, W.L., NASH, R.C. (2005) Why do Privatized Firms Improve Performance? Evidence from Developed Countries, Journal of Corporate Finance, Vol. 11, pp.747-766.

ESTACHE, A., GONZALES, M., TRUJILLO, L. (2002) Efficiency Gains from Port Reform and the Potential for Yardstick Competition: Lessons from Mexico, World Development, Vol. 30, pp. 545-560.

FAGEDA, X. (2011) Load Centers in the Mediterranenen Port Range: Ports Hub and Ports Gateway. $40^{\text {th }}$ Congress of the European Regional Science Association, Barselona.

FLEMING, D., BAIRD, A. (1999) Comment. Some Reflections on Port Competition in the United States and Western Europe, Maritime Policy and Management, Vol. 26, pp. 383-394. 
HARALAMBIDES, H. E. (2002) Competition, Excess Capacity and the Pricing of Port Infrastructure, International Journal of Maritime Economics, Vol. 4, pp. 323-347.

HEAVER, T. (1995) The Implications of Increased Competition among Ports for Port Policy and Management, Maritime Policy and Management, Vol. 27, pp. 125-133.

HEAVER, T., MEERSMAN, H., Van De Voorde, E. (2001) Cooperation and Competition in International Container Transport: Strategies for Ports, Maritime Policy and Management, Vol. 28, pp. 293-305.

JIMENEZ, G., SALAZ, V., SAURINA, J. (2006) Determinants of Collateral, Journal of Financial Economic, Vol. 81, pp. 255-281.

KHAN, M., KUMAR, M.S. (1997) Public and Private Investment and the Growth Process in Developing Countries, Oxford Bulletin of Economics and Statistics, Vol. 59, pp. 69-88.

LIU, N., GAN, H., CHEN, S. (2011) An Analysis of the Competition of Ports in the Shanghai International Shipping Hub, National University of Singapore, Working Paper.

MICCO, A., PÉREZ, N. (2002) Determinants of Maritime Transport Costs, Inter-American Development Bank, Research Department, Working Paper 441.

NAGORSKY, B. (1972) Port Problems in Developing Countries: Principles of Port Planning and Organisation, International Association of Ports and Harbours, Tokyo.

NEWBERY, D., POLLITT, M. (1997) The Restructuring and Privatization of Britain's CEGB: Was it Worth it?, Journal of Industrial Economics, Vol. 45, pp. 269-303.

NIEKERK, H. C. (2005) Port Reform and Concessioning in Developing Countries, Maritime Economics \& Logistics, Vol. 7, pp. 141-155.

NOTTEBOOM, T.E. (1997) Concentration and Load Centre Development in the European container port system", Journal of Transport Geography, Vol.5,No.2, pp. 99-115. 
NOTTEBOOM, T.E. (2010) Concentration and the Formation of

Multi-Port Gateway Regions in the European Container Port System:

an Update, Journal of Transport Geography, Vol. 18 (4), pp.567-583.

NOTTEBOOM, T.E. (2012) Dynamics in Port Competition in Europe: Implications for North Italian ports, Workshop 'I porti del Nord', Milano, 18 April 2012.

ORAL, E.Z., KISȘI, H., CERİT, A.G., TUNA, O., ESMER, S. (2007) Port Governance in Turkey, Chapter 8 in Devolution, Port Governance and Port Performance, eds. Mary R. Brooks and Kevin Cullinane, Research in Transportation Economics Vol.17, Elsevier, The Netherlands, pp. 171-184.

SLACK, B., FREMONT, A. (2005) Transformation of Port Terminal Operations: From the Local to the Global, Transport Reviews, Vol. 25, pp. 117-130.

TONGZON, J., HENG W. (2005) Port Privatization, Efficiency and Competitiveness: Some Empirical Evidence from Container Ports (terminals), Transportation Research Part A: Policy and Practice, Vol. 39, pp. 405-424.

TÜRKLIMM (Türkiye Liman İşletmecileri Derneği) (2012) TÜRKLİM Limanc1lık Sektörü Raporu, İstanbul.

WILLIAMS, B. (2003) Domestic and International Determinants of Bank Profits: Foreign Banks in Australia, Journal of Banking and Finance, Vol. 27, pp. 1185-1210.

ZHANG, A., ZHANG, Y., ZHAO, R. (2001) Impact of Ownership and Competition on the Productivity of Chinese Enterprises, Journal of Comparative Economics, Vol. 29, pp. 327-346. 
http://www.ubak.gov.tr

http://www.turklim.org/tr/liman/liste 